\title{
Questionnaire survey on knowledge, attitudes, and behaviour towards viral hepatitis among the Hong Kong public
}

\author{
Henry LY Chan *, Grace LH Wong, Vincent WS Wong, Martin CS Wong, Carol YK Chan, Shikha Singh
}

\section{A B S T R A C T}

Introduction: We aimed to identify gaps in knowledge, attitudes, and behaviours towards viral hepatitis among the Hong Kong public and provide insights to optimise local efforts towards achieving the World Health Organization's viral hepatitis elimination target.

Methods: A descriptive, cross-sectional, selfreported web-based questionnaire was administered to 500 individuals (aged $\geq 18$ years) in Hong Kong. Questionnaire items explored the awareness and perceptions of viral hepatitis-related liver disease(s) and associated risk factors in English or traditional Chinese.

Results: The majority (>80\%) were aware that chronic hepatitis $B$ and/or C could increase the risks of developing liver cirrhosis, cancer, and/or failure. Only $55.8 \%$ had attended health screenings in the past 2 years, and $67.6 \%$ were unaware of their family's history of liver diseases. Misperceptions surrounding the knowledge and transmission risks of viral hepatitis strongly hint at the presence of social stigmatisation within the community. Many misperceived viral hepatitis as airborne or hereditary, and social behaviours (casual contact or dining with an infected person) as a transmission route. Furthermore, $62.4 \%$ were aware of hepatitis B vaccination, whereas $19.0 \%$ knew that hepatitis $C$ cannot be prevented by vaccination. About $70 \%$ of respondents who were aware of mother-to- knowledge as well as the likelihood of seeking screening were observed across all age-groups and education levels.

Conclusions: Comprehensive hepatitis education strategies should be developed to address gaps in knowledge among the Hong Kong public towards viral hepatitis, especially misperceptions relevant to social stigmatisation and the importance of preventive measures, including vaccination and screening, when exposed to risk factors.

\section{1,2 HLY Chan *, MD \\ $1,3,4,5$ GLH Wong, MD \\ 1,3,4,5 VWS Wong, MD \\ 1,6 MCS Wong, MD \\ ${ }^{7}$ CYK Chan, PhD \\ ${ }^{8} \mathrm{~S}$ Singh, $\mathrm{PhD}$}

Hong Kong Med J 2022;28:45-53

https://doi.org/10.12809/hkmj219463

1 Faculty of Medicine, The Chinese University of Hong Kong, Hong Kong Department of Internal Medicine, Union Hospital, Hong Kong

Department of Medicine and Therapeutics, The Chinese University of Hong Kong, Hong Kong

${ }^{4}$ Medical Data Analytic Centre (MDAC), The Chinese University of Hong Kong, Hong Kong

Institute of Digestive Disease, The Chinese University of Hong Kong, Hong Kong

JC School of Public Health and Primary Care, The Chinese University of Hong Kong, Hong Kong

Gilead Sciences, Hong Kong

${ }^{8}$ Kantar Health, Singapore

* Corresponding author: hlychan@cuhk.edu.hk

New knowledge added by this study

- General awareness of potential risks of viral hepatitis developing into liver cirrhosis, cancer, or liver failure.

- Many still had misperceptions in terms of knowledge and transmission risk of viral hepatitis, suggestive of social stigma or discrimination towards infected individuals.

- Gaps in knowledge about viral hepatitis and likeliness to seek medical screening were observed across all agegroups, especially in respondents with secondary or higher education.

Implications for clinical practice or policy

- We emphasise the importance of preventive measures including screening, diagnosis, treatment, and care to effectively manage viral hepatitis in Hong Kong.

- It is essential to develop universal education strategies to address misperceptions relevant to social stigmatisation, aligning with the community's preferences for various information media channels to optimise information reception. 


\section{香港市民對病毒性肝炎的知識、態度及行為的 問卷調查 \\ 陳力元、黃麗虹、黃煒楸、黃至生、陳怡君、Shikha Singh \\ 引言：我們旨在檢視香港公眾對病毒性肝炎知識、態度和行為的落 差, 並提供優化本地工作的見解, 實現世界衛生組織的消除病毒性肝 炎目標。}

方法：對香港500名市民（年齡 18 歲或以上）進行描述性橫斷面自我 報告的網絡問卷調查。問卷提供英語及繁體中文版本, 項目包括對病 毒性肝炎相關肝病及相關危險因素的認識和看法。

結果：大部份受訪者（超過80\%）意識到慢性乙型和 / 或丙型肝炎會 增加肝硬化、癌症和 / 或衰竭的風險。僅 $55.8 \%$ 在過去 2 年進行健康 檢查, $67.6 \%$ 不知道其家族有肝病史。圍繞病毒性肝炎的知識和傳播 風險的誤解強烈暗示社區內存在社會污名化。許多人將病毒性肝炎誤 解為空氣傳播或遺傳性肝炎, 並將社交行為 (例如與感染者隨意接 觸或用餐）視為傳播途徑。此外, 62.4 受訪者認識乙肝疫苗接種, 而 $19.0 \%$ 知道丙肝疫苗不能通過疫苗接種來預防。約 $70 \%$ 知道母嬰傳播 的受訪者願意在懷孕時就醫。在所有年齡組別和不同教育水平的受訪 者中都觀察到其對病毒性肝炎的知識及節查意願的落差

結論：應制定全面的肝炎教育策略, 以解決香港公眾對病毒性肝炎的 知識差距, 尤其與社會污名化相關的誤解, 以及暴露於風險因素時的 預防措施, 包括疫苗接種和篩查的重要性

\section{Introduction}

Viral hepatitis is a major public health burden worldwide and is the predominant aetiology of liver cirrhosis and/or liver cancer., ${ }^{1,2}$ At least 325 million individuals were reported to be infected with viral hepatitis B (HBV) and/or C (HCV)., ${ }^{2,3}$ Hong Kong is considered an endemic area with intermediate incidence of HBV infection. ${ }^{4}$ In a local epidemiological study conducted between 2015 and 2016, the seroprevalence of hepatitis B surface antigen (HBsAg) was estimated at $7.8 \%$ among the general population..$^{5}$ In contrast, the prevalence rate of HCV infection in Hong Kong has remained low. The seroprevalence of anti-HCV positivity among new blood donors was $0.06 \%$ in 2017, compared with $0.11 \%$ in $2008 .^{6}$ The local HCV prevalence among the general population between 2015 and 2016 was estimated at $0.5 \%,{ }^{5}$ which has remained relatively unchanged since 1992 .

In 2016, the World Health Organization (WHO) implemented a global elimination strategy targeted to achieve at least a $90 \%$ diagnosis rate of all viral hepatitis cases, an $80 \%$ treatment rate for all diagnosed cases, and a $90 \%$ reduction in the incidence of viral hepatitis cases. ${ }^{3}$ Recent epidemiological studies in Hong Kong revealed that the diagnosis and treatment uptake rates within the community were significantly lacking, hovering around 50\% compared with the WHO's $90 \% / 80 \%$ targets. ${ }^{5,8}$ It has been suggested that inadequate knowledge and awareness about viral hepatitis $B$ and $\mathrm{C}$ within Hong Kong's community might be driving this deficiency. ${ }^{5,8-10}$ In other parts of the world, social stigma arising from poor knowledge has been reported to reduce diagnosis and treatment rates among high-risk individuals. ${ }^{11-13}$

In 2020, the Hong Kong Viral Hepatitis Action Plan (HKVHAP) 2020-2024 was launched to facilitate achieving the WHO's eradication target goals by 2030. The action plan outlined four major strategies: (1) Awareness, (2) Surveillance, (3) Prevention, and (4) Treatment to monitor and implement local efforts towards achieving the WHO's 2030 elimination target. ${ }^{14}$

In the present study, we aimed to explore the knowledge, attitudes, and behaviour within Hong Kong's general population pertaining to viral hepatitis and related risk factors. Furthermore, in this study, we sought to identify potential gaps in existing knowledge, attitudes, and behaviour related to the WHO's global viral hepatitis elimination strategy to optimise local efforts towards the WHO's target goal.

\section{Methods}

\section{Study population}

Potential respondents were recruited through an existing, general purpose (ie, not healthcare-specific) web-based consumer panel via email in February 2020. Respondents who were aged $\geq 18$ years, had access to online or comfort with web-based administration, and were able to read English or traditional Chinese were eligible to participate in the study. There were no exclusion criteria for this study. All eligible respondents explicitly agreed to join the panel and provided informed online consent to participate in the study.

Assuming 95\% confidence intervals and 50\% response distribution, responses collected from 500 adult individuals were deemed sufficient to provide descriptive estimates with $4.33 \%$ margin of error.

\section{Study design}

Items pertaining to awareness and perceptions of liver diseases among the general public were explored using a self-administered web-based survey. The survey questionnaire was developed in English and translated into traditional Chinese. The translation was validated by a linguist from a translation company who is a native speaker of the language. The developed questionnaire was reviewed and finalised by a steering committee comprising gastroenterology and/or hepatology experts from 11 countries/territories as part of a regional liver index study (Lee Mei-hsuan et al, unpublished). All 
respondents completed the questionnaire in either English or Chinese. Only de-identified data were collected.

\section{Survey questionnaire}

The internal consistency of the questionnaire from the regional liver index study was assessed by Cronbach's alpha (threshold: alpha $>0.7$ ). As part of this study's objective to explore the knowledge, attitudes, and behaviour of Hong Kong's public towards viral hepatitis-related liver diseases, seven items were extracted from the questionnaire used in a regional liver index study. These items pertained to the awareness and knowledge of liver diseases as well as the respondents' attitudes and behaviours towards screening and diagnosis of liver diseases (online supplementary Appendix 1; Q1-7).

Seven screener questions (online supplementary Appendix 1; S1-7) pertaining to the respondents' socio-demographic characteristics, including age, sex, education, monthly household income, and their awareness of different types of hepatitis were also included in this study.

Respondents who indicated their awareness of 'hepatitis B' or 'hepatitis C' in screener item S7 proceeded to answer Q1(I)-Q2(I) or Q1(II)-Q2(II). Female respondents who correctly recognised the statement 'from a pregnant mother to her baby' in Q2f(I) or Q2f(II) proceeded to answer Q3c.

\section{Descriptive analysis}

This study was exploratory and descriptive in nature. Respondents' characteristics and responses to the survey questions were summarised and are presented as frequencies and percentages. No statistical analyses were performed.

Missing data were random; all data were reported, including those of respondents who declined to answer certain screener questions, such as on monthly household income. Missing data for any question were excluded from analysis of that question only, not from the whole study.

\section{Results}

\section{Study population characteristics}

Among the respondents, $68.0 \%$ were aged $\geq 35$ years, and $56.0 \%$ were female. Among the respondents, $59.0 \%$ had completed university or higher education, and $76.0 \%$ possessed private insurance. About $70 \%$ of respondents had a monthly household income of $\geq \mathrm{HK} \$ 30000$. The respondents' sex, age, education level, and household income were reflective of Hong Kong's population. ${ }^{15}$ Approximately half of the respondents (55.8\%) self-reported having attended health screenings within the last 2 years, and about $32.4 \%$ of them were aware of their family history pertaining to liver diseases (Table 1).
TABLE I. Characteristics of study population $(n=500)^{*}$

\begin{tabular}{|c|c|}
\hline & No. of respondents \\
\hline \multicolumn{2}{|l|}{ Age-group, y } \\
\hline$<25$ & $60(12.0 \%)$ \\
\hline $25-34$ & $100(20.0 \%)$ \\
\hline $35-44$ & $110(22.0 \%)$ \\
\hline $45-54$ & $110(22.0 \%)$ \\
\hline $55-64$ & $103(20.6 \%)$ \\
\hline$\geq 65$ & $17(3.4 \%)$ \\
\hline \multicolumn{2}{|l|}{ Sex } \\
\hline Male & $220(44.0 \%)$ \\
\hline Female & $280(56.0 \%)$ \\
\hline \multicolumn{2}{|l|}{ Education level } \\
\hline Primary school & $5(1.0 \%)$ \\
\hline Secondary school & $200(40.0 \%)$ \\
\hline University & $244(48.8 \%)$ \\
\hline Postgraduate & $51(10.2 \%)$ \\
\hline \multicolumn{2}{|l|}{ Household income, HKD } \\
\hline$<\$ 10000$ & $18(3.6 \%)$ \\
\hline$\$ 10000-\$ 16999$ & $34(6.8 \%)$ \\
\hline$\$ 17000-\$ 29999$ & $87(17.4 \%)$ \\
\hline$\$ 30000-\$ 49999$ & $165(33.0 \%)$ \\
\hline$\geq \$ 50000$ & $190(38.0 \%)$ \\
\hline Declined to answer & $6(1.2 \%)$ \\
\hline \multicolumn{2}{|l|}{ Medical insurance $^{\dagger}$} \\
\hline Private insurance-self-pay & $380(76.0 \%)$ \\
\hline Private-corporate insurance & $188(37.6 \%)$ \\
\hline $\begin{array}{l}\text { Public insurance (eg, national or } \\
\text { subsidised) }\end{array}$ & $25(5.0 \%)$ \\
\hline None of the above & $71(14.2 \%)$ \\
\hline \multicolumn{2}{|l|}{$\begin{array}{l}\text { Self-reported last health screening } \\
\text { within } 2 \text { years }\end{array}$} \\
\hline Yes & $279(55.8 \%)$ \\
\hline No & $221(44.2 \%)$ \\
\hline \multicolumn{2}{|l|}{$\begin{array}{l}\text { Are you aware of your family history } \\
\text { related to liver disease? }\end{array}$} \\
\hline Yes & $162(32.4 \%)$ \\
\hline No & $338(67.6 \%)$ \\
\hline $\begin{array}{l}\text { Data are shown as No. }(\%) \\
\text { Each respondent could have more t } \\
\text { insurance attribute }\end{array}$ & one medical \\
\hline
\end{tabular}

\section{General knowledge and awareness of hepatitis $B$ and $C$}

A higher proportion of respondents were aware of hepatitis B $(93.0 \%, 465 / 500)$ than hepatitis C $(46.4 \%$, 232/500) [online supplementary Appendix 2]. The majority (>80\%) were aware that hepatitis $\mathrm{B}$ and $\mathrm{C}$ can cause liver failure and increase the risks of developing liver cirrhosis and liver cancer (Fig 1a). 
About $60 \%$ of respondents who were aware of hepatitis B knew that HBV is not airborne (61.5\%) and can be prevented by a vaccine (62.4\%). Only approximately $40 \%(186 / 465)$ of the respondents were aware that hepatitis B is not hereditary (Fig 1a). In contrast, only $19.0 \%(n=44 / 232)$ of those aware of hepatitis $\mathrm{C}$ knew that it cannot be prevented by vaccination, and about half knew that it is neither airborne (54.3\%) nor hereditary (41.8\%) [Fig 1a].

About half of the respondents aged $<25$ years (58.2\%) and 55 to 64 years (46.9\%) were not aware that hepatitis B is preventable by vaccination. More than half of the respondents across all age-groups

(a) Hepatitis B or C can/is...

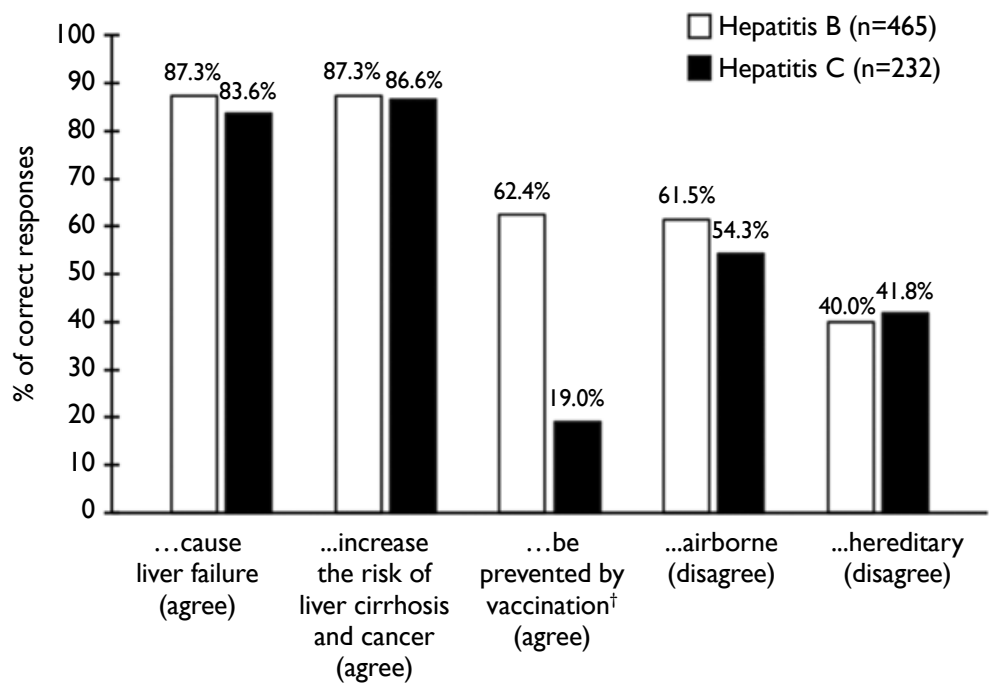

(b) Hepatitis B or C can be transmitted by...

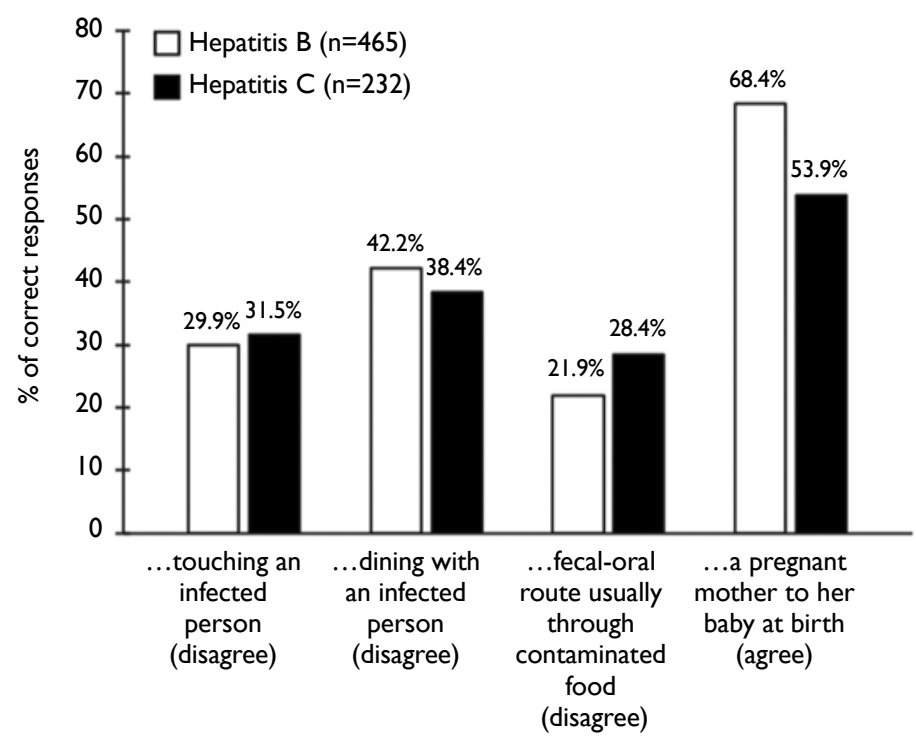

FIG I. Proportion of respondents who correctly identified the features and transmission risks of hepatitis $B$ and $C^{*}$

Correct responses are indicated in brackets, unless otherwise indicated

Correct responses to "...be prevented by vaccination" are "agree" for hepatitis B and "disagree" for hepatitis C were unaware that hepatitis B is not hereditary, with the highest proportion aged $<25$ years $(80.0 \%)$. A substantial proportion of respondents $(>35 \%)$ with either secondary or university education misperceived hepatitis B to be airborne (38.5\%; $39.8 \%)$ or hereditary $(62.0 \%$; $59.7 \%)$ [online supplementary Appendix 3].

More than $70 \%$ of respondents across all agegroups and $>80 \%$ with secondary school or university education misperceived that a vaccine could prevent hepatitis C. About half of subjects aged 25 to 44 years and $\geq 65$ years were not aware that hepatitis $C$ is not airborne, whereas $>70 \%$ of those aged 25 to 34 years and $\geq 65$ years misperceived hepatitis $C$ to be hereditary. More than half of respondents with university $(61.0 \%)$ or postgraduate $(51.9 \%)$ education misperceived hepatitis $\mathrm{C}$ as hereditary (online supplementary Appendix 4).

\section{Knowledge about the transmission risks of hepatitis $B$ and $C$}

At least $30 \%$ of respondents rightly perceived that (1) touching an infected person (HBV: $29.9 \%$; HCV: $31.5 \%)$, (2) the faecal-oral route $(21.9 \% ; 28.4 \%)$; or (3) dining with an infected person $(42.2 \%$; $38.4 \%)$ were not possible modes of transmission of viral hepatitis $\mathrm{B}$ and $\mathrm{C}$ (Fig 1b). More than half of the respondents were aware of the mother-to-child transmission risk of HBV (68.4\%) and HCV (53.9\%) [Fig 1b]. Awareness of other transmission modes of HBV and HCV are detailed in online supplementary Appendix 2.

More than $60 \%$ of respondents across all agegroups and those with at least secondary school education did not correctly identify the transmission risks of HBV (online supplementary Appendix 5): more than half with secondary or university education misperceived touching $(73.3 \% ; 70.4 \%)$ or dining with an infected person $(60.4 \% ; 56.2 \%)$ as HBV transmission risks.

With regard to hepatitis $C$, more than half of the respondents aged $\geq 35$ years and at least $60 \%$ of individuals with at least secondary-level education were unaware or incorrectly identified with the statements regarding social interaction and food contamination as HCV transmission risks. Notably, no respondents with the primary school education level were aware of hepatitis $C$ (online supplementary Appendix 6).

\section{Likelihood of attending health screening in the event of family planning}

Among the 280 female respondents, $65 \%$ correctly identified mother-to-child transmission as a transmission risk of viral hepatitis $\mathrm{B}$ and/or C (Fig 2). Among these respondents, 70.3\% expressed that they were extremely likely or likely to seek a doctor's consultation to get tested if they were or intended to become pregnant (Fig 2). 
Likelihood of seeking hepatitis testing

if I am or planning to be pregnant

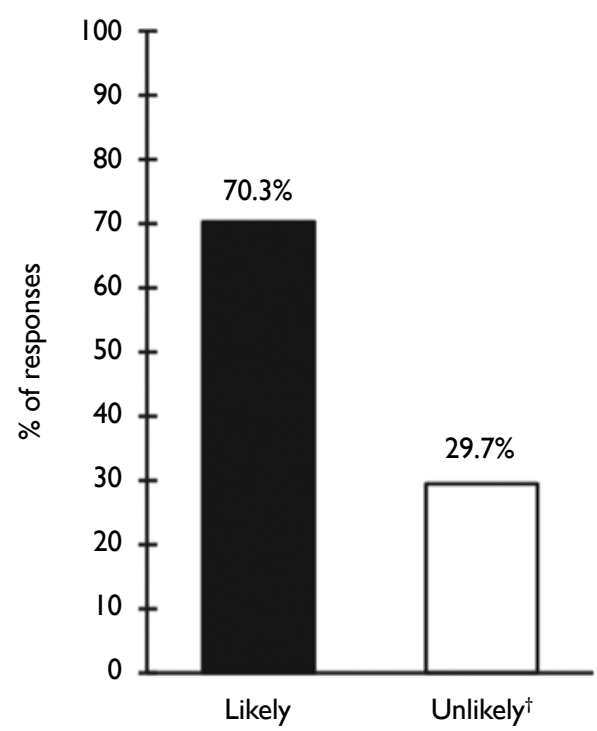

FIG 2. Respondents' self-reported likelihood of seeking doctor's consultation in the event of pregnancy $(n=182)^{*}$

Respondents are females who indicated "agree" to the statement Q2f ("Hepatitis can be transmitted from a pregnant mother to her baby at birth.")

Respondents who indicated 'Neutral','Unlikely', and 'Extremely unlikely'
TABLE 2. Characteristics of respondents who indicated their likelihood of seeking viral hepatitis testing/screening*

\begin{tabular}{lcr}
\hline & Likely & Unlikely \\
\hline $\begin{array}{l}\text { Likelihood of seeking viral hepatitis testing } \\
\text { if I am or planning to be pregnant }\end{array}$ & $128(70.3 \%)$ & $54(29.7 \%)$ \\
\hline Age, y & & \\
\hline$<25$ & $16(53.3 \%)$ & $14(46.7 \%)$ \\
$25-34$ & $25(67.6 \%)$ & $12(32.4 \%)$ \\
\hline $35-44$ & $31(83.8 \%)$ & $6(16.2 \%)$ \\
\hline $45-54$ & $27(69.2 \%)$ & $12(30.8 \%)$ \\
\hline $55-64$ & $28(77.8 \%)$ & $8(22.2 \%)$ \\
\hline 265 & $1(33.3 \%)$ & $2(66.7 \%)$ \\
\hline Education level & & \\
\hline Primary school & 0 & $2(100 \%)$ \\
\hline Secondary school & $46(64.8 \%)$ & $25(35.2 \%)$ \\
\hline University & $71(74.7 \%)$ & $24(25.3 \%)$ \\
\hline Postgraduate & $11(78.6 \%)$ & $3(21.4 \%)$ \\
\hline Household income, HKD & & \\
\hline$<\$ 10000$ & $4(80.0 \%)$ & $1(20.0 \%)$ \\
\hline $10000-\$ 16999$ & $1(14.3 \%)$ & $6(85.7 \%)$ \\
\hline $17000-\$ 29999$ & $28(77.8 \%)$ & $8(22.2 \%)$ \\
\hline $30000-\$ 49999$ & $47(70.1 \%)$ & $20(29.9 \%)$ \\
\hline$\$ 50000$ & $47(71.2 \%)$ & $19(28.8 \%)$ \\
\hline Declined to answer & $1(100 \%)$ & 0 \\
\hline
\end{tabular}

Data are shown as No. (\%). Respondents are females who indicated "agree" to the statement Q2f ("Hepatitis can be transmitted from a pregnant mother to her baby at birth.")

Respondents who indicated 'Neutral', 'Unlikely', and 'Extremely unlikely'

with that observed in $2010(>70 \%) \cdot{ }^{16}$ However, a substantial proportion $(>60 \%)$ of respondents across all age-groups and education levels in Hong Kong held misconceptions about $\mathrm{HBV}$ and $\mathrm{HCV}$ and their transmission risks.

The local awareness of HBV vaccination among Hong Kong respondents (62.4\%) was higher than that of Nigeria $(31.9 \%)^{17}$ but lower than that of Singapore (75.1\%). ${ }^{18}$ Among those unaware of hepatitis B vaccination in Hong Kong, the majority were aged $\geq 25$ years. This is concerning because these respondents were born before the rollout of the local vaccination programme in 1988. Extensive global and local studies have reported that the implementation of $\mathrm{HBV}$ vaccination effectively reduced the incidence and seroprevalence of HBVassociated viral hepatitis. $3,6,14,19,20$ A recent study in Nigeria showed a relationship between HBV vaccination and knowledge about viral hepatitis, ${ }^{17}$ suggesting an unmet need to improve knowledge about HBV to increase HBV vaccination uptake, particularly in older adults.
There was an improved general awareness (>80\%) about the sequelae of $\mathrm{HBV}$ and $\mathrm{HCV}$ compared 
(a) Preferred disease information topics

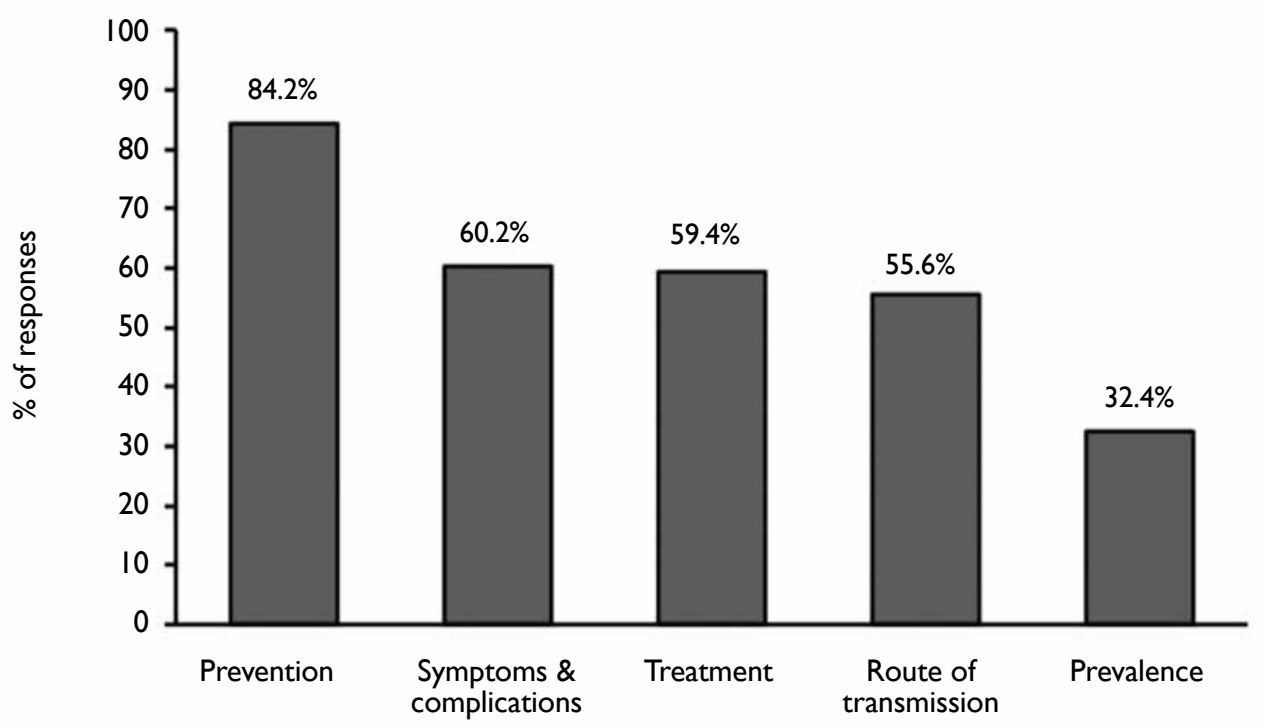

(b) Channels preferred for receiving disease information

Conventional media $\square$ Digital/social media $\quad$ Face-to-face/interpersonal interactions

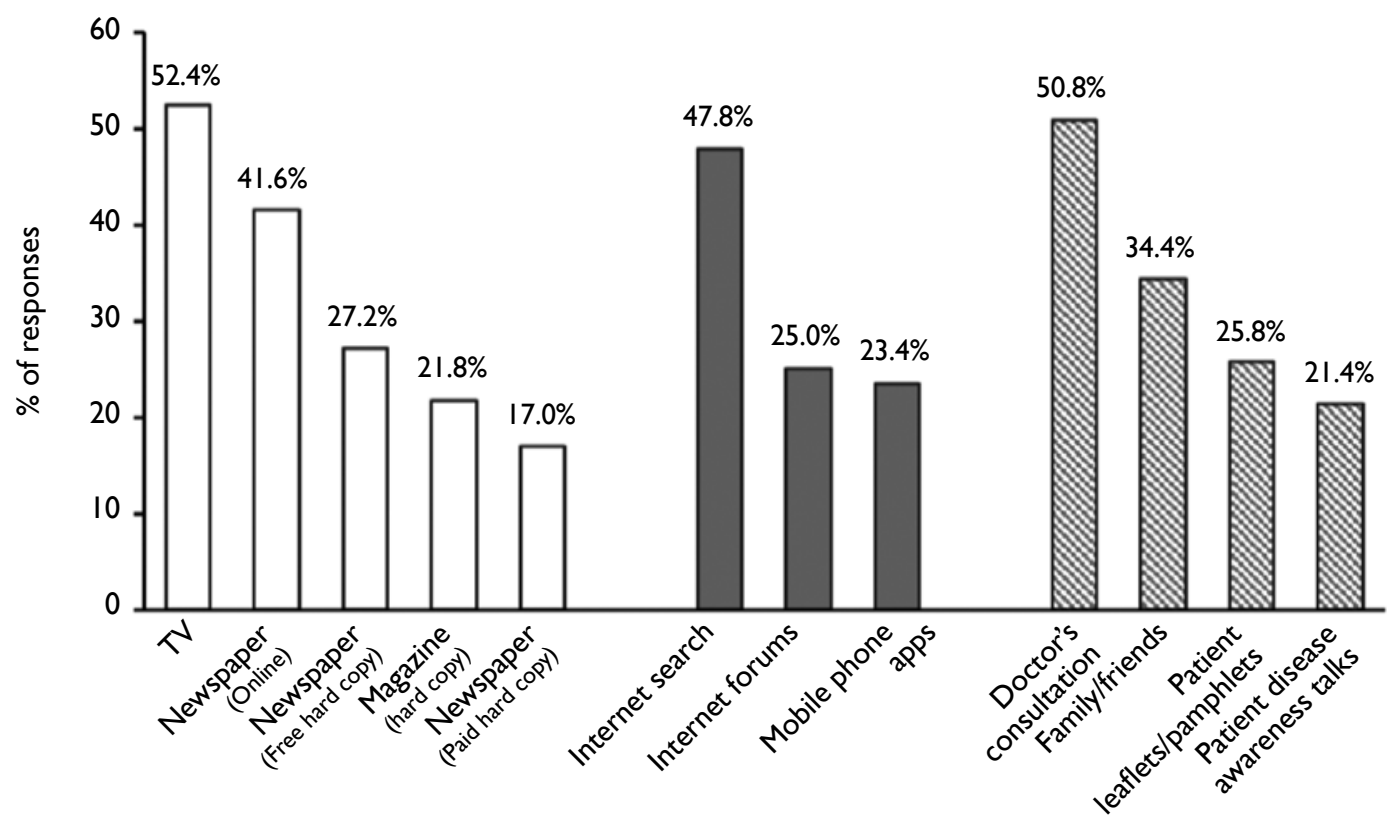

FIG 3. Topics and channels indicated by respondents for receiving disease information $(n=500)$

Moreover, in this study, we observed a general local misperception that a vaccine is available for $\mathrm{HCV}$, which has been similarly observed globally, ${ }^{18,21}$ although we observed a slightly higher local awareness rate $(19.0 \%)$ than that in Singapore (15.0\%). ${ }^{18}$ This lack of awareness pertaining to HCV might impede the adoption of correct preventive measures against hepatitis $C$ infection. ${ }^{22}$
Both the WHO's hepatitis elimination strategy and HKVHAP 2020-2024 emphasised the importance of combating any forms of stigmatisation or discrimination in the implementation of awareness and communication strategies to improve health outcomes among high-risk individuals.,14 Social stigmatisation and discrimination stem from the lack of knowledge within society ${ }^{12,23}$ and among 
healthcare practitioners. $^{10}$ Misperceptions such as the idea that hepatitis can be spread by sharing of food or eating utensils, the faecal-oral route, or touching an infected person (perceived by $>60 \%$ of the study's respondents) often underlie the social stigmatisation surrounding viral hepatitis. ${ }^{16,18,23,24}$ These often result in the avoidance of casual contact, self-isolation, ${ }^{11,23}$ or denial of potential employment or professional advancement, ${ }^{25,26}$ as experienced by infected individuals across the world. Many respondents without $\mathrm{HBV}$ infection in China expressed discomfort about being in close contact or sharing meals with HBV-infected individuals and felt that they should not be allowed to work in restaurants or with children. ${ }^{25}$ Similarly, $55.2 \%$ respondents in a 2019 Korean survey thought HCV patients should use separate towels and dishes, ${ }^{27}$ which is an indication of the misperception of $\mathrm{HCV}$ transmission by causal contact.

Over time, these social behaviours arising from misperceptions could result in a paradox for those infected with viral hepatitis, as stigma and shame could lead them to conceal their condition and avoid seeking the necessary medical treatment. ${ }^{26,28}$ Therefore, there is a need to adopt a comprehensive approach to raise community awareness and knowledge to tackle stigmatisation against infected individuals.

The belief that viral hepatitis is hereditary (ie, it could be inherited through 'bad genes'29) could potentially result in the misunderstanding that there are no preventive measures against viral hepatitis. In fact, mother-to-child transmission is a major route of hepatitis B transmission in Asia. The potential confusion between a vertically transmitted disease and a hereditary one could impede efforts to reduce community transmission of viral hepatitis, as many might not bother to find out more information or proactively seek screening.

The HBsAg seropositivity screening during pregnancy and neonatal vaccination are integral parts of HKVHAP and the WHO's hepatitis elimination strategy to prevent mother-to-child transmission. ${ }^{3,14}$ Prevention of perinatal transmission of $\mathrm{HBV}$ in Hong Kong includes an additional viral load screening of HBsAg-seropositive mothers to guide maternal antiviral therapy. Approximately $70 \%$ of pregnant women in Hong Kong (between May 2017 and December 2019) reportedly did not undergo viral load testing or regular hepatological surveillance before pregnancy. ${ }^{30}$ This is an important public health issue, as viral load in mothers who are hepatitis B carriers is a key influencing factor of immunoprophylaxis success in their babies. ${ }^{31}$ Among the 280 female respondents, only 128 (45.7\%) were aware of the risk of mother-to-child transmission and likely to seek medical consultation in the event of pregnancy, suggesting a gap in women's awareness and knowledge about viral hepatitis in Hong Kong.

Besides vertical transmission, horizontal spread is also an important means of HBV infection. In this study, $67.6 \%$ of respondents were unaware of their family's history of liver disease(s), and only $50 \%$ knew that sexual contact is a transmission risk of HBV and HCV (online supplementary Appendix 2). This suggests an unmet need to educate the community about not only mother-to-child transmission, but also other transmission risks. More robust education efforts are needed to raise the population's level of knowledge and awareness about viral hepatitis to work towards the WHO's elimination goal. Such outreach efforts could be aligned with the respondents' preferences for information media channels such as TV, internet search, and doctor's consultation to optimise community reception.

This study has some limitations. Being a selfadministered cross-sectional study based on selfreported data, the study is subject to recall bias. As such, data validation could not be performed, and no causal associations could be made. Respondents who lack internet access or comfort with online administration could be underrepresented. Furthermore, this study did not consider factors that could influence respondents' levels of knowledge and/or awareness or attitudes towards HBV and HCV (eg, respondents' health consciousness or vaccination or hepatitis status). With $<60 \%$ having attended a health screening in the past 2 years and $<70 \%$ expressing a high likelihood of medical consultation when exposed to risk factors, it would be insightful to explore the reasons for these gaps in proactive health-seeking behaviours. This would facilitate addressing and dispelling concerns to promote precautionary measures and health-seeking behaviours to reduce community transmission.

As this study is exploratory and descriptive in nature, statistical analyses were not performed to evaluate factors associated with the gaps in knowledge, awareness, and/or practices pertaining to hepatitis $B$ and $C$; thus, the associations of respondents' characteristics could not be identified in this study. Additional analyses would be warranted in future studies to confirm any independent factors associated with the community's levels of knowledge and awareness.

\section{Conclusions}

In this study, we found that respondents had a general awareness of hepatitis B and C. However, our findings revealed gaps in respondents' knowledge and understanding of the transmission risks of hepatitis B and $C$ as well as awareness of their family history related to liver disease(s). The findings suggest that there may be social stigmatisation or discrimination against people with $\mathrm{HBV}$ and $\mathrm{HCV}$ 
within the community, which may deter some from undergoing screening and diagnosis.

It is essential to develop targeted education strategies with special attention towards addressing misperceptions relevant to social stigmatisation or discrimination and raise the importance of preventive measures such as vaccination and screening when exposed to risk factors. Outreach of such targeted education efforts should be aligned with the community's preferred information channels to maximise information accessibility.

\section{Author contributions}

Concept or design: All authors.

Acquisition of data: S Singh.

Analysis or interpretation of data: All authors.

Drafting of the manuscript: All authors.

Critical revision of the manuscript for important intellectual content: All authors.

All authors had full access to the data, contributed to the study, approved the final version for publication, and take responsibility for its accuracy and integrity.

\section{Conflicts of interest}

HLY Chan is an advisor to AbbVie, Aligos, Arbutus, Gilead Sciences, GSK, Hepion, Janssen, Merck, Roche, Vaccitech, Venatorx, and Vir Biotechnology; and a speaker for Gilead Sciences, Mylan, and Roche.

GLH Wong has served as an advisory committee member for Gilead Sciences; as a speaker for Abbott, Abbvie, Bristol-Myers Squibb, Echosens, Furui, Gilead Sciences, Janssen and Roche; and received a research grant from Gilead Sciences.

VWS Wong served as a consultant or advisory board member for 3V-BIO, AbbVie, Allergan, Boehringer Ingelheim, the Center for Outcomes Research in Liver Diseases, Echosens, Gilead Sciences, Hanmi Pharmaceutical, Intercept, Inventiva, Merck, Novartis, Novo Nordisk, Perspectum Diagnostics, Pfizer, ProSciento, Sagimet Biosciences, TARGET PharmaSolutions, and Terns; and a speaker for AbbVie, Bristol-Myers Squibb, Echosens, and Gilead Sciences. He has received a grant from Gilead Sciences for fatty liver research. He is also a Co-founder of Illuminatio Medical Technology Limited.

As an editor of the Journal, MCS Wong was not involved in the peer review process for this article.

\section{Acknowledgement}

The authors acknowledge valuable support from Dr Vince Grillo of Kantar Health overseeing the development of the project. The authors thank Dr Amanda Woo of Kantar Health for providing medical writing and editorial support, which was funded by Gilead Sciences, Hong Kong, in accordance with Good Publication Practice (GPP3) guidelines (http:// www.ismpp.org/gpp3). The translation of the questionnaire from English to traditional Chinese was performed by GlobaLexicon Limited, United Kingdom and funded by Gilead Sciences, Hong Kong. The authors acknowledge the members of the steering committee for their contribution in reviewing and finalising the questionnaire: Dr Mei-hsuan Lee, National
Yang Ming Chiao Tung University (Taiwan); Dr Sang-hoon Ahn, Yonsei University College of Medicine (South Korea); Dr Henry LY Chan, Union Hospital (Hong Kong); Dr Asad Choudhry, Chaudhry Hospital (Pakistan); Dr Rino Alvani Gani, University of Indonesia (Indonesia); Dr Rosmawati Mohamed, University of Malaya (Malaysia), Dr Janus P Ong, University of the Philippines (Philippines); Dr Akash Shukla, King Edward Memorial Hospital, Global Hospital (India); Dr Chee-kiat Tan, Singapore General Hospital (Singapore); Dr Tawesak Tanwandee, Siriraj Hospital, Mahidol University (Thailand); and Dr Pham-thi Thu Thuy, Ho Chi Minh Medic Medical Center (Vietnam).

\section{Funding/support}

This study was funded by Gilead Sciences, Hong Kong. Kantar Health, Singapore, received funding from Gilead Sciences, Hong Kong, for the conduct of the study and development of the manuscript.

\section{Ethics approval}

All eligible respondents explicitly agreed to join the panel and provided informed online consent to participate in the study.

\section{References}

1. Asrani SK, Devarbhavi H, Eaton J, Kamath PS. Burden of liver diseases in the world. J Hepatol 2019;70:151-71.

2. World Health Organization. Hepatitis in the Western Pacific. Available from: https://www.who.int/ westernpacific/health-topics/hepatitis. Accessed 3 Aug 2020.

3. World Health Organization. Global Health Sector Strategy on Viral Hepatitis, 2016-2021: towards ending viral hepatitis. Available from: https://apps.who.int/iris/ bitstream/handle/10665/246177/WHO-HIV-2016.06-eng. pdf;jsessionid=F5934335456A761C7349258535E3E5EC?s equence $=1$. Accessed 14 Dec 2020.

4. Lin AW, Wong KH. Surveillance and response of hepatitis B virus in Hong Kong Special Administrative Region, 19882014. Western Pac Surveill Response J 20163;7:24-8.

5. Liu KS, Seto WK, Lau EH, et al. A territory-wide prevalence study on blood-borne and enteric viral hepatitis in Hong Kong. J Infect Dis 2019;219:1924-33.

6. Viral Hepatitis Control Office, Special Preventive Programme, Centre for Health Protection, Department of Health, Hong Kong SAR Government. Surveillance of viral hepatitis in Hong Kong-2017 update report. Available from: https://www.chp.gov.hk/files/pdf/viral_hepatitis report.pdf. Accessed 14 Jan 2021

7. Chan GC, Lim W, Yeoh EK. Prevalence of hepatitis C infection in Hong Kong. J Gastroenterol Hepatol 1992;7:117-20.

8. Hui YT, Wong GL, Fung JY, et al. Territory-wide population-based study of chronic hepatitis $\mathrm{C}$ infection and implications for hepatitis elimination in Hong Kong. Liver Int 2018;38:1911-9.

9. Lao TT, Sahota DS, Suen SS, Lau TK, Leung, TY. Chronic hepatitis B virus infection and rubella susceptibility in pregnant women. J Viral Hepat 2010;17:737-41.

10. Paterson BL, Backmund M, Hirsch G, Yim C. The depiction of stigmatization in research about hepatitis C. Int J Drug Policy 2007;18:364-73.

11. Zacks S, Beavers K, Theodore D, et al. Social stigmatization 
and hepatitis $\mathrm{C}$ virus infection. J Clin Gastroenterol 2006;40:220-4.

12. Mokaya J, McNaughton AL, Burbridge L, et al. A blind spot? Confronting the stigma of hepatitis B virus (HBV) infection-a systematic review. Wellcome Open Res 2018;3:29.

13. Marinho RT, Barreira DP. Hepatitis C, stigma and cure. World J Gastroenterol 2013;19:6703-9.

14. Viral Hepatitis Control Office, Department of Health, Hong Kong SAR Government. Hong Kong Viral Hepatitis Action Plan 2020-2024. Available from: https://www.hepatitis.gov. hk/english/document_cabinet/action_plan.html. Accessed 04 Dec 2020.

15. Census and Statistics Department, Hong Kong SAR Government. Population and Household Statistics Analysed by District Council District. Available from: https://www. statistics.gov.hk/pub/B11303012019AN19B0100.pdf. Accessed 14 Jan 2021.

16. Leung $\mathrm{CM}$, Wong WH, Chan $\mathrm{KH}$, et al. Public awareness of hepatitis B infection: a population-based telephone survey in Hong Kong. Hong Kong Med J 2010;16:463-9.

17. Eni AO, Soluade MG, Oshamika OO, Efekemo OP, Igwe TT, Onile-ere OA. Knowledge and awareness of hepatitis B virus infection in Nigeria. Ann Glob Health 2019;85:56.

18. Tan CK, Goh GB, Youn J, Yu JC, Singh S. Public awareness and knowledge of liver health and diseases in Singapore. J Gastroenterol Hepatol 2021 Mar 18. Epub ahead of print. Available from: https://onlinelibrary.wiley.com/doi/ abs/10.1111/jgh.15496. Accessed 2 May 2021.

19. Meireles LC, Marinho RT, Van Damme P. Three decades of hepatitis B control with vaccination. World J Hepatol 2015;7:2127-32.

20. Posuwan N, Wanlapakorn N, Sintusek P, et al. Towards the elimination of viral hepatitis in Thailand by the year 2030. J Virus Erad 2020;6:100003.

21. Ha S, Timmerman K. Awareness and knowledge of hepatitis $\mathrm{C}$ among health care providers and the public: a scoping review. Can Commun Dis Rep 2018;44:157-65.
22. Wait S, Kell E, Hamid S, et al. Hepatitis B and hepatitis C in southeast and southern Asia: challenges for governments. Lancet Gastroenterol Hepatol 2016;1:248-55.

23. Lee H, Fawcett J, Kim D, Yang JH. Correlates of hepatitis B virus-related stigmatization experienced by Asians: a scoping review of literature. Asia-Pac J Oncol Nurs 2016;3:324-34.

24. Smith-Palmer J, Cerri K, Sbarigia U, et al. Impact of stigma on people living with chronic hepatitis B. Patient Relat Outcome Meas 2020;11:95-107.

25. Huang J, Guan ML, Balch J, et al. Survey of hepatitis B knowledge and stigma among chronically infected patients and uninfected persons in Beijing, China. Liver Int 2016;36:1595-603.

26. Northrop JM. A dirty little secret: stigma, shame and hepatitis $C$ in the health setting. Med Humanit 2017;43:21824.

27. Choi GH, Jang ES, Kim JW, Jeong SH. A survey of the knowledge of and testing rate for hepatitis $\mathrm{C}$ in the general population in South Korea. Gut Liver 2020;14:808-16.

28. Gautier RL, Wallace J, Richmond JA, Pitts M. The personal and social impact of chronic hepatitis B: a qualitative study of Vietnamese and Chinese participants in Australia. Health Soc Care Community. 2020. Available from: https:// onlinelibrary.wiley.com/doi/abs/10.1111/hsc.13197. Accessed 27 Jan 2021.

29. Haga SB, Barry WT, Mills R, et al. Public knowledge of and attitudes toward genetics and genetic testing. Genet Test Mol Biomarkers 2013;17:327-35.

30. Hui PW, Ng C, Cheung KW, Lai CL. Acceptance of antiviral treatment and enhanced service model for pregnant patients carrying hepatitis B. Hong Kong Med J 2020;26:318-22.

31. Cheung KW, Seto MT, Wong SF. Towards complete eradication of hepatitis $\mathrm{B}$ infection from perinatal transmission: review of the mechanisms of in utero infection and the use of antiviral treatment during pregnancy. Eur J Obstet Gynecol Reprod Biol 2013;169:1723. 